\title{
Why Small States Offer Important Answers to Large Questions
}

Comparative Political Studies 20I5, Vol. 48(4) 527-549

(C) The Author(s) 2014

Reprints and permissions: sagepub.com/journalsPermissions.nav DOI: $10.1177 / 00104 \mid 4014554687$

cps.sagepub.com

(S)AGE

\section{Wouter P. Veenendaal' and Jack Corbett ${ }^{2}$}

\begin{abstract}
Small states are conspicuously absent from mainstream comparative political science. There are a variety of reasons that underpin their marginal position in the established cannon, including their tiny populations, the fact that they are not considered "real" states, their supposedly insignificant role in international politics, and the absence of data. In this article, we argue that the discipline is much poorer for not seriously utilizing small states as case studies for larger questions. To illustrate this, we consider what the case study literature on politics in small states can offer to debates about democratization and decentralization, and we highlight that the inclusion of small states in various ways augments or challenges the existing literature in these fields. On this basis, we argue that far from being marginal or insignificant, the intellectual payoffs to the discipline of studying small states are potentially enormous, mainly because they have been overlooked for so long.
\end{abstract}

\section{Keywords}

democratization and regime change, decentralization, quality of democracy, small states, comparative politics

\footnotetext{
'Royal Netherlands Institute of Southeast Asian and Caribbean Studies, Leiden, The Netherlands

${ }^{2}$ Griffith University, Brisbane, Australia, and the Australian National University, Canberra, Australia
}

\section{Corresponding Author:}

Wouter P. Veenendaal, Royal Netherlands Institute of Southeast Asian and Caribbean Studies, Reuvensplaats 2, Leiden, 23II BE, The Netherlands.

Email: veenendaal@kitlv.nl 


\section{Introduction}

In comparative political research, the smallest countries in the world are largely excluded. Although there are significant differences in the threshold that scholars apply to exclude small states, almost all publications in this field do employ a cutoff point that results in their elimination. In Samuel Huntington's (1991) seminal The Third Wave, for example, all countries with less than 1 million inhabitants were excluded, and in Arend Lijphart's (1999) Patterns of Democracy, no countries with less than a quarter of a million people were analyzed. Even though the resulting number and proportion of excluded states may be quite high, many scholars do not provide a substantive justification for their decision to omit them. The assumption is implicit: Small states do not matter. This has not always been the case, however. Decolonization and the emergence of small states as members of international organizations in the 1970s gave rise to a body of work specifically interested in their politics (Plischke, 1977; Rapaport, Muteba, \& Therattil, 1971; Reid, 1974; Vital, 1971). This rationale has since dissolved. Small states are no longer new, they occupy a marginal position in global affairs, they have tiny populations, and so they tend to be ignored.

In this article, we make the case for why small states matter in comparative politics. Our rationale is methodological; to meet the standard conventions of case selection - representativeness and variation (Gerring, 2007) —we argue that comparative scholars need to pay closer attention to small states. If small states have similar political arrangements to large states, then we are wasting valuable data by not including them in our analysis. If they are different - and the strong statistical correlation between democratization and small size, for example, suggests that they are (D. Anckar, 2002a; Diamond \& Tsalik, 1999; Srebrnik, 2004) - then we are missing out on the insights that these diverse, extreme, deviant, or most different cases offer (Geddes, 1990; Seawright \& Gerring, 2008). When comparing "like with like," it might make sense to focus exclusively on large states (Dogan \& Pelassy, 1984), but when seeking generalizability, we argue that there are few, if any, persuasive reasons that would justify the omission of small states in the systematic way that has become accepted practice.

To support our argument that small states matter, we explore the rationale that scholars give for why small states are excluded from their studies, focusing on comparative politics in particular. We identify five explanationsinsignificant population size, they are not "real" states, that others exclude them too, the absence of data, and the perceived need to compare similar systems - that we discuss further below. This article is premised on the assumption that all states have an intrinsic scholarly value, no matter their 
size, in global comparative politics. However, to illustrate the shortcomings of these rationales, and to show what the study of politics in small states can offer, we provide a detailed examination of two of the largest debates in the discipline in which small states are commonly excluded: democratization and decentralization. First, we show that systematically overlooking two of the most successful regions in terms of democratization-the Pacific and the Caribbean - greatly distorts our understanding of the causes and stimuli of democratic transition. In particular, we show that contra to received wisdom, democratic development in poor societies is clearly possible, but the extent to which this is the case can only be observed if small states assume a more prominent place in our analysis. Second, by overlooking how democracy works in small states, we also miss the important lessons the interplay between size and democratic institutions offers for important post-transition topics such as decentralization, where normative questions about scale are paramount. As a result, far from being marginal or insignificant, the intellectual payoffs to the discipline of studying small states are potentially enormous, mainly because they have been overlooked for so long (cf. Sharman, in press).

Before we begin, let us first address some definitional issues. When talking about small states, definitions of state size and cutoff points are important, and since at least the 1950s, an academic debate has emerged on the conceptualization of state size. The size of states can be measured on the basis of multiple variables, including population, territory, economic indicators, or military capabilities. In addition, this scholarly debate has also focused on the question of categorization; that is, how a state should rank on these variables to be classified as a small state or a microstate (cf. Alesina \& Spolaore, 2005; D. Anckar, 2010; Crowards, 2002; Downes, 1988; Taylor, 1969). As most publications in the field of comparative political science have done, this article conceptualizes state size on the basis of population figures. As scholars have used different population thresholds to exclude small states, this article does not employ one specific cutoff point to determine what constitutes a "small state." Rather, one of our aims is to show how employing these arbitrary cutoff points impacts on the findings of much comparative research. Importantly, because there is a clear global trend toward eversmaller states (Lake \& O'Mahony, 2004), irrespective of the definition we employ, the number of small states has steadily grown in recent decades. As a result, to omit states with less than 500,000 inhabitants would now mean that approximately $15 \%$ of the available cases are excluded from analysis. This figure grows to more than $20 \%$ if the population threshold is raised to 1 million. ${ }^{1}$ In light of the broadly acknowledged methodological principle that all available observations (or a representative sample of this) should be analyzed to avoid selection bias, the unfounded exclusion of such a large proportion of cases can only be deemed unacceptable. 


\section{Why Small States Are Excluded}

A survey of the most well-known and renowned publications in the field of comparative politics and democracy demonstrates that scholars draw from several well-rehearsed reasons for excluding small states. Indeed, it often appears to be the case that scholars are unconscious about their exclusion of small states, because most studies do not even devote attention to explaining their omission. With the exception of a small number of studies, the major works in comparative politics or comparative democratization exclude the smallest of all states, for reasons that typically remain unclear or unconvincing. Among the most prominent explanations are that:

1. small states represent only a tiny proportion of the world's population (e.g., Huntington, 1991; Moore, 1995);

2. small states are not "real" or fully independent states (e.g., Vanhanen, 1997);

3. other authors in this academic field exclude small states as well (e.g., LeDuc, Niemi, \& Norris, 2002; Lijphart, 1999);

4. there is a structural lack of data on small states (e.g., Powell, 1984; Vanhanen, 1997); and

5. the principle of "most similar" comparison is more appropriate in some circumstances (e.g., Rhodes, Wanna, \& Weller, 2009, p. 11).

The first of these arguments alludes to the relative insignificance of small states, and scholars who refer to this reason often also mention the fact that small states are unknown to the larger public. If the overall aim of comparative political research is, however, to derive knowledge from the comparison of political systems, it is not clear why the number of people that a system serves should be the most significant factor that determines whether a country is worthy of study. In terms of scholarly value, each case, no matter how small, can derive new insights into the way politics works. Indeed, by studying the systems of understudied nations, instead of those that we already know much about, we are likely to learn much more (cf. Sharman, in press). That is not to say that all questions or topics necessitate the inclusion of small states, but, as we will show below, some of the biggest questions in the discipline would definitely benefit from their inclusion.

The second argument can be seen as an attempt to set small states apart from other states by denying them the classification as a state. The validity of this argument is dependent on the specific definition of a "state" each author employs. However, most small states relatively easily meet the most common criteria of statehood; ${ }^{2}$ all of them have a certain territory and population, and all (being UN 
members) are recognized as sovereign states by other states. When it comes to political or economic dependence on other states, this argument could also be applied to many larger and underdeveloped African states that are crucially dependent on development aid or countries such as Greece that have recently committed themselves to wide austerity measures and thereby have arguably ceded sovereign control of their public finances to others. On this basis, it is unclear why such states are included in most studies, whereas small states are not.

The third and fourth arguments are related in the sense that the application of the third actually contributes to the problem of the fourth. Although the initial reason for selecting any cutoff point is often not clarified if authors refer to previous publications that have also excluded small states, it is likely to result from a lack of data. Whereas it is true that there is a structural lack of data on the smallest of all states, it can be asserted that this is primarily a consequence of the fact that earlier studies and databases excluded these countries, and it would logically appear that this pattern can only be reversed if future studies pay greater attention to small states (cf. Lemke, 2003). Furthermore, although a lack of data may have been an acceptable ground for eliminating small cases in the past, data on small states are now available via numerous organizations and websites (Ott, 2000). ${ }^{3}$

The fifth argument, we concede, is the most legitimate and we would not want to dismiss the value of "most similar" case comparison (much of our work has focused on small states at the exclusion of larger ones). However, for the good of the discipline as a whole, we maintain that this type of work should be complemented by analysis that incorporates diverse case selection. More importantly, given implicit preference for focusing on large cases, the payoffs, as we will show, of studying small cases are likely to be exponentially more beneficial. Indeed, if there is an argument for more "most similar" case selection, it could justify support for more work on small states. As we illustrate in the remainder of the article, excluding two of the most successful regions in terms of democratization - the Pacific and the Caribbean - greatly distorts our understanding of the causes and stimuli of democratic transition. And, because these states offer unique insights into how small polities work, they have significant implications for topics such as decentralization where questions about scale are of supreme importance.

\section{What Small States Have to Offer}

Having highlighted that the majority of the contemporary classics in comparative politics exclude small states, we nevertheless concede it is fair to ask how problematic the exclusion of this group of cases actually is, and so we devote the remainder of this article to demonstrating what small states offer 
as case studies. In particular, we focus on two of the largest debates in the discipline - democratization and decentralization-where the literature on politics in small states is obviously relevant. In doing so, we highlight how the inclusion of small states augments or challenges existing analysis.

\section{Example One: The Democratization Debate}

The first example we consider is the correlation between modernization and democratization. In doing so, we highlight the extent to which claims that follow from this literature are applicable to small states, most of which tend to be excluded from publications in this field. Perversely, as we will demonstrate, this often mentioned cause and stimulus of democratization does not provide credible insights when looking at transition toward democracy in small states, which means that the inclusion of these states appears to weaken the overall robustness and applicability of this literature. ${ }^{4}$

When discussing how commonly cited theories of democratization resonate with the experience of small states, Huntington's (1991) The Third Wave is a good starting point. Huntington famously observed that the democratic transition of some 30 countries in Latin America, Southern and Eastern Europe, Asia, and Africa between 1974 and 1990 resulted in a global increase in the number of democracies from nearly $25 \%$ to more than $45 \%$, constituting a "Third Wave" (p. 26). However, in making this claim, Huntington excluded countries with populations of less than 1 million. If he had included all available countries that became democratic between 1974 and 1990, the number of democratizing states would have risen from 36 to 56, according to Freedom House. ${ }^{5}$ Initially, utilizing the full sample rather than just over half of the available dataset would have significantly bolstered Huntington's case. The full impact of this omission is, however, best demonstrated by the way it has biased the subsequent Huntington-inspired literature on global democracy trends.

At the dawn of the new millennium, it became apparent that many of the states Huntington classified as "Third Wave" cases remained stuck in the "grey zone" between democracy and authoritarianism (Carothers, 2002, p. 9), and some even slid back to outright dictatorship (Levitsky \& Way, 2002; O'Donnell, 1996; Zakaria, 1997). The expected transition to liberal democracy did not materialize in many countries, and some scholars even suggested that a third "reverse wave" might follow (Diamond, 1996, p. 31). However, if the experience of the 20 excluded small states were taken into account, this so-called "reversal" is far less significant than these studies presume. Freedom House continues to classify all but one-Solomon Islands - as a full democracy, and this exception is questionable. ${ }^{6}$ At the very least, the inclusion of all countries, big or small, would nuance the "reversal" story by highlighting how the Third Wave had a much more permanent impact in small states than 
in larger ones. Taken together, the significantly smaller proportion of reversals weakens the "grey zone" claim as the Third Wave of democratization has, when all countries are considered, been much more enduring than is habitually understood. To make this observation, however, small states need to assume a more prominent place in our analysis.

When looking at the specific cases or regions that are generally excluded from the democratization literature, it can be noted that the two world regions in which we can find most of the very small states - the Caribbean and the Pacific - are both in various publications hailed as the most democratic regions of the developing world (e.g., D. Anckar, 2002b; Srebrnik, 2004). In emphasizing the prevalence of democracy in the Caribbean region, Jorge Domínguez (1993) stipulates that "no other region in what has been called the Third World has had, for so long, so many liberal democratic polities" (p. 2), whereas Benjamin Reilly (2002) refers to the Pacific as "a region of remarkable success in terms of democratic continuity" (p. 355). In light of the democratic successes of these regions, it is quite striking that studies of democratic development in the non-Western world tend to virtually exclude the two areas in which democratization has been most successful - both in terms of its scope and durability. In Africa, where democracies are scarce and democratic development has arguably been least successful, small-state exclusion leads to the omission of the democratic small island states of Cape Verde, São Tomé and Príncipe, and sometimes also Mauritius, which almost reduces the total number of African democracies by a third (cf. Van de Walle, 2002). ${ }^{7}$

In Western Europe, the situation seems to be reversed, because the least democratic states in this region are the Principalities of Liechtenstein and Monaco and the episcopal state of Vatican City. The Principalities maintain a monarchy with significantly more wide-ranging powers than larger European monarchies, while the Vatican City is ruled as a theocracy. So, even the most cursory glance at small states in Africa, the Caribbean, Europe, and the Pacific shows divergence from the broader regional patterns of democratization. However, to flesh this point out more fully, we will delve deeper into some of the most prominent suppositions about the causes and stimuli of democratic transition and consolidation, but in doing so we will include the experience of small states, particularly in the Pacific and the Caribbean. Specifically, we canvass the most often named democracy-stimulating factor: a high level of economic development.

\section{Modernization Theory: Economic Development and Democratization}

The most widely embraced democracy-stimulating factor is economic development, sometimes referred to as wealth or modernization. The main 
argument of modernization theory, as first formulated by Seymour Martin Lipset and later adopted by many scholars, is that the improvement of the material and social conditions of the lower classes generates a more favorable attitude toward democracy and a decreased tendency to revolt (Lipset, 1959; Pinkney, 2003). While the correlation between modernization and democracy is rarely disputed, the causal relationship between the two has been questioned by the work of Przeworski (2000), who found that an increase in gross domestic product (GDP) per capita does not cause democratic governance, but rather that rising income levels reduce the likelihood that democracies will slide back or revert to authoritarian rule, as economic crisis is "one of the most common threats to democratic stability" (cf. Przeworski, Alvarez, Cheibub, \& Limongi, 1996, p. 41). This adjustment of modernization theory has attracted some critique by those who argue that it retains explanatory power as a causal variable (e.g., Boix \& Stokes, 2003; Epstein, Bates, Goldstone, Kristensen, \& O'Halloran, 2006). For our purposes, this controversy is largely irrelevant as we question the applicability of the correlation, causal or otherwise, in the case of small states. Importantly, all of the aforementioned studies exclude many or all small states, either because of a lack of data on economic development in these countries (e.g., Przeworski, 2000) ${ }^{8}$ or because they rely on an aggregate index of democracy such as Polity-IV (e.g., Epstein et al., 2006).

Economic development is related to many other variables, which are all supposed to have a positive effect on democracy and which are therefore generally subsumed under the same cluster variable (often labeled "modernization theory"). These variables include, among others, industrialization and education (Barro, 1999; Gasiorowski \& Power, 1998; Hadenius, 1992; Huntington, 1991; Lipset, 1959; Powell, 1984). According to the modernization school, the combination of economic development, industrialization, and education creates a society whose citizens are overall more assertive and politically aware. Consequently, incentives to participate in formal politics grow, and because of increased education and knowledge, citizens are less susceptible to the rhetoric of demagogues and populist leaders (Lipset, 1959). Economic development is also said to lead to the emergence of an educated and politically critical middle class, which serves as a powerful counterforce to authoritarian rule (Huntington, 1991; Lipset, 1959; Muller, 1995). The final variable that is associated with modernization theory is social equality (Pinkney, 2003; Przeworski et al., 1996; Tilly, 2003), which when combined with the redistribution of wealth-which may be a consequence of economic development and industrialization - is supposed to increase the emotional attachment of the citizenry to the democratic process (Tilly, 2003).

For a long time, democratic but extremely poor India was seen as the major deviant case of modernization theory, and later the African 
democratizing states of Botswana, Ghana, Namibia, and South Africa have been added to this list. On the other side of the spectrum, counterevidence for the theory has been found in the examples of the wealthy yet undemocratic Persian Gulf states and the Southeast Asian countries of Singapore and Brunei. Only rarely has attention been paid to the largest group of poor, yet with few exceptions, democratic states in the Pacific. Out of the 11 small island states in the region covered by Freedom House, 9 are classified as democracies as of 2014 (Freedom House, 2014). Intriguingly, the two exceptions - Fiji and the Solomon Islands - are also the largest countries in terms of population size, although the classification of Solomon Islands, the smaller of the two, is questionable given elections in 2006 and 2010 (see Note 6). With the exception of Palau, all Pacific Island states have gross national income (GNI) per capita levels of below US $\$ 10,000$ (International Monetary Fund [IMF], 2014), and therefore rank similar to the bulk of African and Asian states.

Whereas industrialization and education are seen as core elements in the hypothesized causal connection between economic development and democratization, the Pacific small island states (but also small states in other world regions) because of their scale are disadvantaged on both counts (for a detailed discussion, see Connell, 2013). Economic development via industrialization has proved virtually impossible in the Pacific for a combination of well-known factors, including small populations, limited natural resources, remoteness, geographic and cultural fragmentation, vulnerability to external economic shocks, susceptibility to extreme events such as cyclones and earthquakes, dependence on imports, and fragile environments. Putting industrialization aside, economic growth and development remain constrained by disadvantages associated with economies of scale, which include high communication and energy costs, irregular transport routes, the disproportionate cost of public administration and infrastructure, skills shortages, and the absence of domestic capital. Historically, colonial powers experimented with plantation agriculture - especially bananas and sugarcane - in these territories, but the global market for these commodities has since declined. Alternatives, such as tourism, have been successful in some small states, but this industry remains susceptible to global market volatility, and diversification remains a major challenge. Indeed, since the 1980 s, economists have been referring to small states in the Pacific, but also elsewhere, as MIRAB (Migration, Remittances, Aid and Bureaucracy) economies (Bertram $\&$ Watters, 1985) due to their reliance on external assistance for the provision of basic services.

Similarly, high levels of education, a product of economic growth, is also central to the modernist argument. Historically, most Pacific Island countries 
have not had national universities, which means that islanders have to go abroad to acquire their diplomas and often do not return afterward, resulting in a migratory brain drain that undermines economic capacity. This problem is particularly acute for governments who often find it difficult to fill key administrative posts. Capacity issues also loom large in donor accounts of governance problems in the Pacific, as outlined in the last consolidated round of Legislative Needs Assessments conducted by the United Nations Development Program (Morgan \& Hegarty, 2003), for example. Indeed, echoing the basic assumptions of the modernization thesis, prior to elections, significant donor effort goes into educating voters in the Pacific about the democratic process. More generally, the challenge of achieving economic modernization has contributed to renewed attention about the vulnerabilities of small states among international organizations, with the United Nations having set up the Small Island Developing States (SIDS) Network, for instance.

Combined, all of these factors are said to stifle economic growth prospects and stunt the associated democratic dividend that large-scale modernization ought to provide, and yet, across the region, elections are held (around 200 in the 13 independent or self-governing Pacific Island countries since the 1960s) and the process of compromise and conciliation typical of this type of government is largely maintained. Indeed, even in a country such as Nauru, where momentous economic crisis during the late 1990s and early 2000s (Connell, 2006; Hughes, 2004) should, in theory, have caused the breakdown of democratic rule, democracy has survived despite ongoing political volatility. Perversely, the two countries in the Pacific with the strongest growth prospects due to their relatively larger size and natural resource endowments-Fiji and Solomon Islands - have had the most trouble sustaining democratic government. As Peter Larmour (1996) points out, rather than aiding democracy, in the Pacific, modernist development appears to undermine it.

A similar observation can be made for the African small island states and Cape Verde and São Tomé and Príncipe in particular. Both countries made the transition from a Marxist single-party state with a socialist economy to multiparty democracy in the early 1990s, and since then have continuously produced democratically elected governments. GDP per capita levels are, however, quite similar to African averages, with a figure of around US $\$ 4,000$ for Cape Verde and US\$2,000 for São Tomé and Príncipe. Both countries form part of a group of five former Portuguese African colonies, but the two lusophone small island nations have strongly outperformed their larger continental counterparts of Angola, Guinea Bissau, and Mozambique. Whereas all five former Portuguese colonies obtained independence in the mid-1970s 
and all five subsequently transformed into single-party Marxist states, the three continental cases have experienced civil war, oppressive regimes, and major political turmoil. By contrast, smaller and insular Cape Verde and São Tomé and Príncipe experienced a relatively smooth transition to multiparty democracy in the early 1990s and have since then maintained their democratic regimes, despite persistently low economic performance (B. Baker, 2006; Frynas, Wood, \& Soares de Oliveira, 2003; Meyns, 2002; Seibert, 1999).

In total, the number of democracies across the world with GDP per capita levels less than US\$10,000 is 11 if a population threshold of 1 million citizens is applied. If the threshold is removed, however, the Freedom House figure rises to 23, with the Caribbean states of Belize and Guyana added to the African and Pacific examples, meaning that more than half of low-income democracies are small states. As such, the experience of these small states forms a challenge to the core assumptions of modernization theory and significantly weakens its claim to being a necessary precondition for democratization. Democratic development in poor societies is clearly possible, but the extent to which this is the case can only be observed if small states are included in our analysis. Consequently, while our discussion is not exhaustive - there is much more that can be said about democratization based on the experience of small states - it is illustrative of the importance of these states when considering answers to questions of this nature.

\section{Example Two: The Decentralization Debate}

In many larger states around the world, in the last decades, a clear trend toward decentralization and devolution of government services to smaller, subnational units can be observed. This trend is buttressed by the notion that "small is beautiful" (Schumacher, 1973) and that much is to be gained from organizing politics in smaller units, thus bringing the government closer to the people (Weldon, 2006). To illustrate the value of small states to scholars of comparative politics, as a second example we consider what the literature on the politics of these countries adds to this debate. Specifically, we draw on Diamond and Tsalik's (1999) chapter "Size and Democracy: The Case for Decentralization," which, despite being somewhat dated, nevertheless lays out the case for decentralization in an accessible and cogent manner, is explicitly comparative, and, most importantly from the perspective of this article, makes clear - albeit elliptical and largely erroneous - reference to the practice of politics in small states in the preamble to the main argument.

A few caveats before we begin. First, we acknowledge that the literature on decentralization is extensive, unwieldy, and includes a number of related 
concepts such as devolution and multi-level governance. We do not and cannot provide an exhaustive review of this literature here but have instead restricted our scope for the reasons mentioned above. Second, we do not seek to refute Diamond and Tsalik's (1999) argument by restating why centralization, as a normative standard, is the ideal institutional type; we are in fact broadly sympathetic to the case they prosecute. Our point is both more modest and fundamental. The question that underpins this debate is what is the ideal size for a democratic polity? We argue that an empirical answer must, almost by definition, pay close attention to the practice of democracy in small states. In doing so, we illustrate how this material adds a level of much needed nuance to current understandings. Third, much of the small states literature we draw on in this discussion has been published since Diamond and Tsalik's piece and so, obviously, we do not critique them for not using it. However, while we predominantly employ the most up-to-date literature-much of which is drawn from our own research - the main thrust of this newer material in relation to the advantages and pitfalls of small size has been canvassed previously (see R. Baker, 1992; Dommen \& Hein, 1985; Rapaport et al., 1971; Vital, 1971).

Essentially, Diamond and Tsalik (1999) argue that when it comes to democratic politics, small is beautiful. Like others who make this point, their starting point is Dahl and Tufte's (1973) seminal work, although, as Baldacchino (2012) notes, this argument has deep roots in antiquity and an idealized version of classical Greek democracy. To set up their discussion, they highlight the well-known correlation between state size and democratic consolidation. That is, in contrast to many of the authors discussed above, Diamond and Tsalik do not ignore small states altogether. Rather, despite no discussion of how democracy is practiced in small states, they make this correlation the linchpin of their argument by positing that if, as the correlation suggests, small size is conducive to democratization, we should seek to mimic the conditions of small size in larger states, that is, adopt a decentralized model that devolves power to regions, municipalities, and other subnational units:

If institutional arrangements such as federalism and decentralization can mimic in some important respects the conditions of small states, then perhaps larger states may benefit from some of the same favourable conditions for democracy that are intrinsic to very small states. (Diamond \& Tsalik, 1999, p. 120)

But what are these conditions that Diamond and Tsalik (1999) consider so conducive to democratic practice? They provide five conditions: citizen development, accountability and responsiveness, representativeness, checks and balances, and contingent consent. We discuss each in turn but, in contrast 
to Diamond and Tsalik, we also incorporate the extant literature on the practice of politics in small states. Again, our aim is not to refute arguments in favor of decentralization but rather illustrate how paying closer attention to small states would enrich this discussion.

\section{Citizen Development}

The first argument that Diamond and Tsalik (1999) make for why small is more democratic is that it allows for more direct or personal participation of large sections of the citizenry in the political process, especially for women and minorities. As a result, it increases awareness of how issues are debated and decisions reached, thus providing support for unpopular decisions. In turn, this "prodemocratic socialization" (p. 123) ensures that citizen trust in their democracy is higher in larger states where voters are further removed from centers of power. As a result:

Ordinary citizens will be more likely to accept policies that hurt their immediate interests if they understand and are involved in the decisions leading to these policy choices and in the efforts to implement them locally ... [generating] a "civic culture" of tolerance, trust, reciprocity and cooperation. (Diamond \& Tsalik, 1999, p. 124)

The problem with this assessment is that it does not match the findings of the case study literature on the practice of politics in small states, where (a) politics remains dominated by elites, who, in developing economies in particular, have much higher levels of education than the average citizen, thus allowing them to control the policy agenda (see Corbett, 2013a; Corbett \& Wood, 2013); (b) localized loyalties and personality politics undermine the consolidation of national-level bureaucracies (see Corbett, 2013b) leading in some cases to "weak" or "failed" states (e.g., Connell, 2006); (c) in the developing economies of the Pacific and parts of the Caribbean, these dynamics are often described as contributing to pervasive patron-client politics, including votebuying (see R. Duncan \& Hassall, 2011; N. T. Duncan \& Woods, 2007); and (d) while there are no large-scale citizen surveys that gauge levels of antipolitical sentiment that Diamond and Tsalik (1999) see as undermining democracy in larger states, imported institutional systems are often compared unfavorably with forms of "traditional" governance that are, perversely, more commonly associated with tolerance, trust, reciprocity, and cooperation than democracy. Finally, as we will flesh out further below, minorities are still marginalized in small states. Indeed, small states often have powerful cultures of compliance that stifle pluralism and dissent (see Baldacchino, 2012; 
Crocombe, 2008). Moreover, when it comes to women's representation, the small island states of the Pacific region are among the worst performing in the world (see Fraenkel, 2006).

\section{Accountability and Responsiveness}

The second argument is that democratic local government boosts legitimacy by encouraging policy makers to be more responsive to the needs of citizens. Drawing on Dahl and Tufte (1973), Diamond and Tsalik (1999) argue:

As the size of constituencies increase, chains of communication between the people and their representatives become longer and more bureaucratized, citizens have (by sheer numerical odds) less chance of having their views and interests advanced by their representatives. (p. 129)

Intuitively, this makes sense. However, when it comes to the responsiveness of politicians, population size is never the only relevant factor at play. Many small states are also island states or, more significantly, archipelagic island states. ${ }^{9}$ In such circumstances, communication between citizens and their electorates, let alone access to constituencies, can be fraught with complexity. For example, in Kiribati, the capacity of the member for Washington Island to visit his or her constituency is limited by the shipping schedule (on average a ship visits the island twice a year). Moreover, while in recent years radio communication has been established between the island and the capital, it is irregular at best (the link is often broken for months at a time). This is an extreme but not uncommon example and the same principles that relate to isolation are at work when politicians undertake overseas trips as airline routes between small states (and island states in particular) are infrequent, causing lengthy delays and stopovers that keep leaders from constituency work. Similarly, as mentioned, because many small states are also relatively poor, parliament is often underresourced, and so members tend not to have vehicles or staffing allocations, for example, limiting their capacity to visit their constituencies. Combined, these factors illustrate the accusation that "leaders don't come to us" (Diamond \& Tsalik, 1999, p. 126) is not restricted to large states. Perversely, often for good reasons, it can be more acute in small ones. The lesson for advocates of greater decentralization is that the size of a polity is never the only factor influencing the nature of representation.

A similar point can be made about accountability. As we will discuss further below, because of the reduced social proximity common to small states, there is a natural level of transparency not afforded to larger states. In this 
respect, small can be beautiful. On the contrary, the clear lines of accountability so prized by the liberal ideal are almost impossible to sustain in a small-state context where individuals are called upon to play multiple roles, leading to persistent criticisms of nepotism and corruption (Corbett, 2013a; Veenendaal, 2014a). In extreme cases, small can also be easy to dominate, with numerous instances of populist leaders treating smaller countries as personal "fiefdoms" due to their control over nearly all aspects of social life (see Crocombe, 2008, p. 643). Moreover, the argument that devolution of power provides a more precise means for citizen redress (Diamond \& Tsalik, 1999) understates the extent to which politics in small polities is, by definition, intensely personalized - especially in microstates where electorates often only have a few hundred voters - with electors also relatives or kin. Analyzing the African microstate of São Tomé and Príncipe, Seibert (1999), for example, writes that "political actions stem from essentially personal relations based on individual contact rather than the indirect, administrative relationships and formal contacts that dominate in a larger society" (p. 316). Naturally, in such circumstances, familial loyalties tend to override policy priorities and assessments of MP competence that accord with more utilitarian principles.

\section{Representativeness}

The third argument hinges on the increasing professionalization of politics in larger states where politicians, to use the common Weberian distinction, live "off" rather than "for" politics. In turn, the accusation is that these members become insulated from the electorate by their party bureaucracies and instead pay more attention to the moneyed interests, who fund their campaigns, than citizen needs. By holding out the possibility of a return to a "politics for amateurs," decentralization, and its associated emphasis on citizen participation, is seen as an answer to the increased professionalization of the political classes in larger states (e.g., see Stoker, 2006).

Empirically, there is something to this point as politics can retain an "amateur" quality in small states that it has long been lost in other parts of the world (Corbett, 2013b); but, this does not necessarily entail greater representativeness (Veenendaal, 2013). As we have discussed, politicians still tend to be elites in small states even if they do not live "off" politics. Moreover, there are downsides to amateur politics, including, as we have discussed, the absence of resourcing that can curtail constituent access. However, the biggest flaw in this argument is that it ignores the extent to which politicians in small states are unfavorably compared with their more "professionalized" counterparts in larger states. Donors in the Pacific and Caribbean, for example, spend significant sums of money trying to professionalize politics and 
politicians through parliamentary training programs and "party aid." Their rationale is that more professional politicians are less likely to perpetuate personalized politics that are believed to undermine "good governance," a model explicitly drawn from large states.

\section{Checks and Balances}

The fourth argument is that small size provides a structural bulwark against authoritarian rule. Again, an elliptical view of the correlation between small size and democratization would support this view. However, if we dig a little deeper, this assumption becomes more problematic. First, in some instances, small states-Fiji, Grenada, Seychelles, and Suriname-have reverted to authoritarian rule. Second, as outlined, while a minimalistic version of democracy may be maintained in small states, smallness can stifle pluralism. This can occur informally via social and cultural sanctions that curb dissent (Baldacchino, 2012). But, it can also happen through formal mechanisms. Newspapers and other media, for example, are considered key avenues for holding governments to account in large states, but, as discussed above, in small states, genuine independence of the press is harder to sustain due to the economies of scale. As a result, news providers are often government owned and therefore open to manipulation and co-option by ruling elites. As Baker (2008) writes of Seychelles, "the government still controls the SBC [the national broadcasting company] and the only daily paper, the Nation, and seems very reluctant to allow others into the field" (p. 287).

\section{Contingent Consent}

Finally, the willingness of losers at an election to accept the results or outcome of the popular ballot is, according to Diamond and Tsalik (1999), enhanced in decentralized systems as power is dispersed among different levels of the government. Again, this argument makes sense in theory but is less persuasive in practice. First, some small states do not have political parties (Veenendaal, 2014b), and, even in those that do, personalization and localization often matter more than policy platforms. In such circumstances, instability, not entrenched control, is seen to be a major problem. The presidency of Nauru changed nine times during the 1990s, while 2003 saw five presidents in 1 year as, in the absence of institutionalized parties, politicians regularly switch sides (Connell, 2006). And, while this turnover rate is high even by small-state standards, this type of instability is not uncommon, especially in the Pacific (Fraenkel, 2009).

But, second, how small or devolved should a polity be? For example, the island nation of Palau, with a population of around 20,000, does have a 
federated model along the lines that Diamond and Tsalik (1999) advocate. The National Congress of Palau has a bicameral parliament with 25 MPs in total. Each of the 16 states also has a state legislature, governor, lieutenant governor, bureaucracy, Council of Chiefs, and so on, including the state of Hatohobei (or Tobi), which has a voting population of approximately 100 citizens who elect a 9-member legislature. Diamond and Tsalik argue that it is worth forgoing a degree of efficiency to achieve the benefits of decentralization but, one can assume, they might rethink this assessment in the Palauan case. This example, of course, is extreme, but the more generalizable point is that all centralized governments, no matter their population size, remain open to the criticism that they do not pay enough attention to local concerns.

Diamond and Tsalik (1999) are not naive to the endogenous problems of decentralization and federalism. Indeed, they provide a fairly extensive discussion of the pitfalls of a devolved approach, including canvassing some of the points we have raised. Again, however, this discussion is primarily drawn from the experience of large states and as a result does not acknowledge some of the advantages that small size has for democratic practice that, if they had engaged with these cases in greater depth, would have further bolstered their argument. We have already touched on a number of these in the above discussion and so we will not rehash them here as our primary aim has not been to refute Diamond and Tsalik and thus defend centralization but rather illustrate how paying greater attention to small states as case studies offers important insights relevant to these questions. The overarching lesson for the decentralization debate that emerges from the literature on the practice of politics in small states is that at best small size provides mixed blessings. Consequently, while decentralization may ameliorate some of the problems that scholars identify with the practice of politics in larger states, the creation of smaller political units will, inevitably, generate some of their own.

\section{Conclusion-Why Small States Can Offer Important Answers to Large Questions}

Our call, therefore, is for scholars of comparative politics to be more reflexive about their exclusion of small states and its negative repercussions for the subjects they study. At the very least, we hope that this recognition will encourage scholars to consider size as a factor when choosing cases, even if they ultimately opt for a "most similar" approach to selection. Furthermore, if a choice is made to leave out small states, in our opinion, scholars should also explain and justify their threshold of exclusion, that is, why countries below a certain size are less interesting cases than those that rank above this cutoff point. We hope, however, that future studies will more often include 
small states in their analyses. Based on the two examples we explored, we have shown that systematically overlooking two of the most successful regions in terms of democratization - the Pacific and the Caribbean - greatly distorts our understanding of the causes and stimuli of transition and consolidation. And that by ignoring how democracy works in small states, we have missed important lessons for topics such as decentralization where questions about the ideal size of a polity are paramount.

Ultimately, we believe that the exclusion of small states comes at a great cost to the study of comparative politics. As the average size of countries around the globe continues to decrease, and the call for power to be devolved to localized authorities grows, research on the political effects of size is increasingly relevant and warranted. In these circumstances, the experience of smaller states becomes even more important to scholars of comparative politics, and it is our hope that this article has illustrated why.

\section{Acknowledgment}

We would like to thank Terence Wood, Jason Sharman, Patrick Weller, and three anonymous reviewers for their comments and suggestions, which have helped us to strengthen the manuscript and sharpen our core arguments.

\section{Declaration of Conflicting Interests}

The authors declared no potential conflicts of interest with respect to the research, authorship, and/or publication of this article.

\section{Funding}

The authors received no financial support for the research, authorship, and/or publication of this article.

\section{Notes}

1. These figures are exclusively based on sovereign states (with UN membership). The figures become even more dramatic if nonsovereign jurisdictions such as British Overseas Territories and French Départements d'Outre Mer (DOMs) are included, because these polities tend to be small in size.

2. As they were codified during the Montevideo Convention (1933).

3. It can sometimes still be hard, if not impossible, however, to retrieve information about the smallest states. For example, voter turnout statistics of elections in the smallest Pacific Island states are still lacking.

4. We use the Freedom House-ranking of "free" to categorize countries as democracies, even though our own research demonstrates that some of the "free" small island states have characteristics often considered "non-democratic," as we will also show in our discussion on decentralization later in this article. These 
limitations aside, the rankings remain a useful shorthand for the purposes of this discussion.

5. The excluded Third Wave cases are Andorra, Antigua and Barbuda, Belize, Cyprus, Dominica, the Federated States of Micronesia, Grenada, Kiribati, Liechtenstein, the Marshall Islands, Malta, Mauritius, Monaco, St. Kitts and Nevis, St. Lucia, St. Vincent and the Grenadines, Samoa, the Solomon Islands, Tuvalu, and Vanuatu. By omitting these cases, a geographical bias is also included in his analysis (cf. Ott, 2000). The small third wave democracies are primarily located in two regions of the world: the Pacific and the Caribbean. As the Pacific region only contains small democracies and the Caribbean area nearly so as well, only five Caribbean countries (the Bahamas, Barbados, Jamaica, Trinidad and Tobago, and the Dominican Republic) and two Pacific countries (Fiji and Papua New Guinea) are included in Huntington's book. As a result, the Caribbean and the Pacific are significantly underrepresented in The Third Wave.

6. Despite a period of civil unrest in the early 2000s, Solomon Islands has held what are widely considered free and fair elections since 2006.

7. At present, Freedom House ranks 10 African countries as "free," and 3 of these are small island nations (Freedom House, 2014).

8. In Przeworski's (2000) book Democracy and Development, quite a number of small states are excluded because of an apparent lack of data. Przeworski excludes Antigua and Barbuda, Dominica, St. Kitts and Nevis, St. Lucia, St. Vincent and the Grenadines in the Caribbean, Kiribati in the Pacific, and São Tomé and Príncipe in Africa.

9. As most of the contemporary small states are also island nations, it can be hard to disentangle the separate political effects of smallness and insularity (or "islandness"). The focus of the present article is on small states, but the distinctive nature of islands as units of study has generated a literature in its own right. It is beyond our scope here to provide a substantive review, but for additional reading, see McCall (1994), Baldacchino (2008), C. Anckar (2008), and Congdon Fors (2014).

\section{References}

Alesina, A., \& Spolaore, E. (2005). The size of nations. Cambridge, MA: The MIT Press.

Anckar, C. (2008). Size, islandness, and democracy: A global comparison. International Political Science Review, 29, 433-459.

Anckar, D. (2002a). Why are small island states democracies? The Round Table, 365, 375-390.

Anckar, D. (2002b). Democratic standard and performance in twelve pacific microstates. Pacific Affairs, 75, 207-225.

Anckar, D. (2010). Small is democratic, but who is small? Arts and Social Sciences Journal, 2, 1-10.

Baker, B. (2006). Cape Verde: The most democratic nation in Africa. Journal of Modern African Studies, 44, 493-511. 
Baker, B. (2008). Seychelles: Democratising in the shadows of the past. Journal of Contemporary African Studies, 26, 279-293.

Baker, R. (Ed.). (1992). Public administration in small and island states. West Hartford, CT: Kumarian Press.

Baldacchino, G. (2008). Studying islands: On whose terms? Some epistemological and methodological challenges to the pursuit of island studies. Island Studies Journal, 3, 37-56.

Baldacchino, G. (2012). Islands and despots. Commonwealth \& Comparative Politics, 50, 103-120.

Barro, R. J. (1999). Determinants of democracy. The Journal of Political Economy, 107(S6), 158-183.

Bertram, G., \& Watters, R. F. (1985). The MIRAB economy in South Pacific microstates. Pacific Viewpoint, 26, 497-519.

Boix, C., \& Stokes, S. C. (2003). Endogenous democratization. World Politics, 55, 517-549.

Carothers, T. (2002). The end of the transition paradigm. Journal of Democracy, $13(1), 5-21$.

Congdon Fors, H. (2014). Do island states have better institutions? Journal of Comparative Economics, 42, 34-60.

Connell, J. (2006). Nauru: The first failed PacificState? The Round Table, 383, 47-63.

Connell, J. (2013). Islands at risk? Environments, economies and contemporary change. Cheltenham, UK: Edward Elgar.

Corbett, J. (2013a). "Everybody knows everybody": Practising politics in the PacificIslands. Democratization. Advance online publication. doi:10.1080/1351 0347.2013.811233

Corbett, J. (2013b). Politicians and professionalization in the PacificIslands: Revisiting self-regulation? Politics \& Policy, 41, 852-876.

Corbett, J., \& Wood, T. (2013). Profiling politicians in Solomon Islands: Professionalisation of a political elite? Australian Journal of Political Science, 48, 320-334.

Crocombe, R. (2008). The South Pacific. Suva, Fiji: Institute of Pacific Studies.

Crowards, T. (2002). Defining the category of "small" states. Journal of International Development, 14, 143-179.

Dahl, R. A., \& Tufte, E. R. (1973). Size and democracy. Stanford, CA: Stanford University Press.

Diamond, L. J. (1996). Is the Third Wave over? Journal of Democracy, 7(3), 20-37.

Diamond, L. J., \& Tsalik, S. (1999). Size and democracy: The case for decentralization. In L. J. Diamond (Ed.), Developing democracy: Towards consolidation (pp. 117-160). Baltimore, MD: The John Hopkins University Press.

Dogan, M., \& Pelassy, D. (1984). How to compare nations: Strategies in comparative politics. Chatham, NJ: Chatham House.

Domínguez, J. I. (1993). The Caribbean question. In J. I. Domínguez, R. A. Pastor, \& R. D. Worrell (Eds.), Democracy in the Caribbean: Political, economic, and social perspectives (pp. 1-25). Baltimore, MD: The Johns Hopkins University Press. 
Dommen, E., \& Hein, P. (Eds.). (1985). States, microstates and islands. London, England: Croom Helm.

Downes, A. S. (1988). On the statistical measurement of smallness: A principal component measure of country size. Social and Economic Studies, 37(3), 75-96.

Duncan, N. T., \& Woods, D. (2007). What about us? The Anglo-Caribbean democratic experience. Commonwealth \& Comparative Politics, 45, 202-218.

Duncan, R., \& Hassall, G. (2011). How pervasive is clientelist politics in the Pacific? In R. Duncan (Ed.), The political economy of economic reform in the Pacific (pp. 265-276). Mandaluyong City, Philippines: Asian Development Bank.

Epstein, D. L., Bates, R., Goldstone, J., Kristensen, I., \& O'Halloran, S. (2006). Democratic transitions. American Journal of Political Science, 50, 551-569.

Fraenkel, J. (2006). The impact of electoral systems on women's representation in Pacific parliaments (Report for the Pacific Islands Forum Secretariat by the Pacific Institute of Advanced Studies in Development \& Governance). Suva, Fiji: University of the South Pacific.

Fraenkel, J. (2009). Oceania's political institutions and transitions. In S. Levine (Ed.), Pacific ways: Government and politics in the Pacific Islands (pp. 277-302). Wellington, New Zealand: Victoria University Press.

Freedom House. (2014). Freedom in the world. Available from http://www.freedomhouse.org

Frynas, J. G., Wood, G., \& Soares de Oliveira, R. M. S. (2003). Business and politics in Sao Tome e Principe: From cocoa monoculture to petro-state. African Affairs, 102, 51-80.

Gasiorowski, M. J., \& Power, T. J. (1998). The structural determinants of democratic consolidation: Evidence from the third world. Comparative Political Studies, 31, 740-771.

Geddes, B. (1990). How the cases you choose affect the answers you get: Selection bias in comparative politics. Political Analysis, 2, 131-150.

Gerring, J. (2007). Case study research: Principles and practices. Cambridge, MA: Cambridge University Press.

Hadenius, A. (1992). Democracy and development. Cambridge, MA: Cambridge University Press.

Hughes, H. (2004). From Riches to Rags. What Are Nauru's Options and How Can Australia Help? Sydney: Centre for Independent Studies Issue Analysis No. 50.

Huntington, S. P. (1991). The Third Wave: Democratization in the late twentieth century. Norman: University of Oklahoma Press.

International Monetary Fund. (2014). World Economic Outlook Database. Retrieved from http://www.imf.org/external/ns/cs.aspx?id=28

Lake, D. A., \& O’Mahony, A. (2004). The incredible shrinking state: Explaining change in the territorial size of countries. Journal of Conflict Resolution, 48, 699-722.

Larmour, P. (1996). Democracy without development in the South Pacific. In A. Leftwich (Ed.), Democracy and development: Theory and practice (pp. 230247). Cambridge. MA: Polity Press. 
LeDuc, L., Niemi, R. G., \& Norris, P. (2002). Comparing democracies 2: New challenges in the study of elections and voting. London, England: SAGE.

Lemke, D. (2003). African lessons for international relations. World Politics, 56, 114-138.

Levitsky, S., \& Way, L. A. (2002). The rise of competitive authoritarianism. Journal of Democracy, 13(2), 51-65.

Lijphart, A. (1999). Patterns of democracy. New Haven, CT: Yale University Press.

Lipset, S. M. (1959). Some social requisites of democracy: Economic development and political legitimacy. The American Political Science Review, 53, 69-105.

McCall, G. (1994). Nissology: The study of islands. Journal of the Pacific Society, 17(2-3), 1-14.

Meyns, P. (2002). Cape Verde: An African exception. Journal of Democracy, 13(3), 153-165.

Moore, M. (1995). Democracy and development in cross-national perspective: A new look at the statistics. Democratization, 2(2), 1-19.

Morgan, M., \& Hegarty, D. (2003). Strengthening Pacific parliaments: Legislative reform program for Pacific Island countries. Suva, Fiji: United Nations Development Programme-Governance for Livelihoods and Development Project.

Muller, E. N. (1995). Economic determinants of democracy. American Sociological Review, 60, 966-982.

O’Donnell, G. (1996). Illusions about consolidation. Journal of Democracy, 7(2), 34-51.

Ott, D. (2000). Small is democratic: An examination of state size and democratic development. New York, NY: Garland.

Pinkney, R. (2003). Democracy in the third world. Boulder, CO: Lynne Rienner.

Plischke, E. (1977). Microstates in world affairs. Washington, DC: American Enterprise Institute for Public Policy Research.

Powell, G. B., Jr. (1984). Contemporary democracies: Participation, stability, and violence. Cambridge, MA: Harvard University Press.

Przeworski, A. (2000). Democracy and development: Political institutions and wellbeing in the world, 1950-1990. Cambridge, MA: Cambridge University Press.

Przeworski, A., Alvarez, M., Cheibub, J. A., \& Limongi, F. (1996). What makes democracies endure? Journal of Democracy, 7(1), 39-55.

Rapaport, J., Muteba, E., \& Therattil, J. J. (1971). Small states \& territories: Status and problems. New York, NY: Arno Press.

Reid, G. L. (1974). The impact of very small states on international relations. London, England: SAGE.

Reilly, B. (2002). Social choice in the South Seas: Electoral innovation and the Borda count in the pacific island countries. International Political Science Review, 23, 355-372.

Rhodes, R., Wanna, J., \& Weller, P. (2009). Comparing Westminster. Oxford, UK: Oxford University Press.

Schumacher, E. F. (1973). Small is beautiful. London, England: Blond \& Briggs. 
Seawright, J., \& Gerring, J. (2008). Case selection techniques in case study research: A menu of qualitative and quantitative options. Political Research Quarterly, 61, 294-308.

Seibert, G. (1999). Comrades, clients, and cousins: Colonialism, socialism, and democratization in São Tomé and Príncipe. Ridderkerk, The Netherlands: Ridderprint.

Sharman, J. (in press). Sovereignty, survival and hierarchy at the extremes: Microstates and international relations. Unpublished manuscript.

Srebrnik, H. (2004). Small island nations and democratic values. World Development, $32,329-341$.

Stoker, G. (2006). Why Politics Matters. Making Democracy Work. Houndmills: Palgrave Macmillan.

Taylor, C. L. (1969). Statistical typology of micro-states and territories. Social Science Information, 8, 101-117.

Tilly, C. (2003). Inequality, democratization, and de-democratization. Sociological Theory, 21, 37-43.

Van de Walle, N. (2002). Africa's range of regimes. Journal of Democracy, 13(2), 66-80.

Vanhanen, T. (1997). Prospects of democracy. London, England: Routledge.

Veenendaal, W. P. (2013). Political representation in microstates: St. Kitts and Nevis, Seychelles, and Palau. Comparative Politics, 45, 437-456.

Veenendaal, W. P. (2014a). Democracy in microstates: Why smallness does not produce a democratic political system. Democratization. Advance online publication. doi: $10.1080 / 13510347.2013 .820710$

Veenendaal, W. P. (2014b). How democracy functions without parties: The republic of Palau. Party Politics. Advance online publication. doi:10.1177/1354068813509524

Vital, D. (1971). The survival of small states. Oxford, UK: Oxford University Press.

Weldon, S. (2006). Downsize my polity? The impact of size on party membership and member activism. Party Politics, 12, 467-481.

Zakaria, F. (1997). The rise of illiberal democracy. Foreign Affairs, 76(6), 22-43.

\section{Author Biographies}

Wouter P. Veenendaal is postdoctoral researcher at the Royal Netherlands Institute of Southeast Asian and Caribbean Studies in Leiden, The Netherlands.

Jack Corbett is research fellow at the School of Government and International Relations at Griffith University, Brisbane, Australia. 